\title{
Powtoon Based Physics Learning Video Development on Straight Movement Materials for Class X SMA
}

\author{
Ali Chandra" ${ }^{* 1)}$, Muhammad Nasir ${ }^{2)}$, Fakhruddin ${ }^{3)}$ \\ ${ }^{1,2,3)}$ Physics Education, University of Riau \\ Email: alychandra14@gmail.com \\ muhammad.nasir@lecturer.unri.ac.id \\ faruqfisika@yahoo.com
}

\begin{abstract}
The aim of this research was to produce a valid Powtoon-based physics learning video on straight motion material for class $X$ senior high school. The product developed is in the form of a physics learning video based on Powtoon on straight motion material for class $x$ senior high school. The research method uses the ADDIE development model with five stages, namely Analysis, Design, Development, Implementation, and Evaluation. The instrument used is a validation sheet that is given to experts in providing an assessment of the validity of the media. The assessment instrument includes four aspects of the assessment, namely the design aspect, the pedagogic aspect, the content aspect, and the technical aspect. The results of the validation of these four aspects obtained an average score of 4.34. Video meeting 1 got the final score with a value of 4.31. Video meeting 2 got the final score with a value of 4.36. Video meeting 3 got the final score with a value of 4.37. Powtoon-based physics learning media has been successfully designed for three meetings which include straight motion learning material in class X SMA. This learning media has been successfully created using the powtoon application. This learning media has been validated by experts. All experts have stated that every element of the assessment of this learning media is valid, so it is suitable to be used as a medium for learning physics in straight motion material.
\end{abstract}

Keywords: straight motion, ADDIE model, Powtoon. 


\title{
Pengembangan Video Pembelajaran Fisika Berbasis Powtoon pada Materi Gerak Lurus untuk Sma Kelas X
}

\author{
Ali Chandra*1), Muhammad Nasir' ${ }^{2)}$, Fakhruddin ${ }^{3)}$ \\ ${ }^{1,2,3)}$ Pendidikan Fisika, Universitas Riau
}

\begin{abstract}
Abstrak
Tujuan dari penelitian ini adalah menghasilkan video pembelajaran fisika berbasis Powtoon pada materi gerak lurus untk SMA kelas $X$ yang valid. Produk yang dikembangkan berupa video pembelajaran fisika berbasis Powtoon pada materi gerak lurus untuk SMA kelas x. Metode penelitian menggunakan model pengembangan ADDIE dengan lima tahap yaitu Analysis, Design, Development, Implementation, dan Evaluation. Instrumen yang digunakan yaitu lembar validasi yang dibrikan kepada ahli dalam memberikan penilaian kevalidan media. Instrumen penilaian meliputi empat aspek penilaian yaitu aspek perancangan, aspek pedagogik, aspek isi, dan aspk teknis. Hasil validasi dari keempat aspek ini didapat skor rata-rata 4,34. Video pertemuan 1 mendapatkan skor akhir dengan nilai 4,31. Video pertemuan 2 mendapatkan skor akhir dengan nilai 4,36. Video pertemuan 3 mendapatkan skor akhir dengan nilai 4,37. Media pembelajaran fisika berbasis Powtoon telah berhasil dirancang untuk tiga pertemuan yang mencangkup materi pembelajaran gerak lurus di SMA kelas X. Media pembelajaran ini telah berhasil dibuat dengan menggunakan aplikasi Powtoon. Media pembelajaran ini telah divalidasi oleh pakar. Semua pakar telah menyatakan bahwa setiap unsur penilaian dari media pembelajaran ini adalah valid, sehingga layak digunakan sebagai media pembelajaran fisika pada materi gerak lurus
\end{abstract}

Kata Kunci: gerak lurus, model ADDIE, Powtoon.

\section{Pendahuluan}

Perkembangan teknologi informasi yang begitu pesat, seharusnya dapat dimanfaatkan secara bijaksana dalam meningkatkan sumber daya manusia. Sumber daya manusia yang unggul dapat mengantarkan suatu bangsa menjadi maju dan bersaing di kancah global. Pendidikan sebagai salah satu instrumen penting dalam pengembangan sumber daya manusia, karena harus mempunyai kemampuan pengetahuan, sikap, dan keterampilan. Oleh katera itu diperlukan kemampuan menyelenggarakan pendidikan yang menghendaki perencanaan dan pelaksanaan yang matang agar dipeoreh hasil yang yang maksimal (Ika et al, 2016).

Fisika merupakan salah satu cabang utama ilmu pengetahuan alam seperti kimia, biologi, astronomi dan sebagainya. Fisika memiliki ciri khas dalam penalaran kenyataan sesuai aspek-aspek yang memungkinkan pencatatan atau pengamatan indrawi secara langsung (Tobing, 1996). Kenyataannya peserta didik di sekolah menengah sebagian besar menganggap fisika paling sulit. Hal ini karena selain materi dalam mata pelajaran sulit dipahami, penyampaian materi oleh guru kurang menarik perhatian peserta didik. Padahal pelajaran ini merupakan pelajaran yang harus dipahami, bukan hanya dihafalkan. Pengajar fisika di sekolah lebih sering membahas teori dari buku pegangan yang digunakan, serta memberikan rumus-rumusnya lalu memberikan contoh soal (Khairul, 2004).

Salah satu materi fisika yang dianggap sulit adalah pada materi gerak lurus. Hal ini dikarenakan pada topik materi gerak lurus terlalu banyak rumus yang digunakan dan banyak dari peserta didik yang masih menghafal rumus berdasarkan buku ataupun yang disampaikan oleh guru tanpa mencari tahu darimana rumus-rumus itu berasal dan tanpa memahami konsepnya. Hal ini dapat mempengaruhi hasil belajar kognitif peserta didik. Oleh sebab itu, pendidik dituntut memiliki kemampuan merancang kegiatan pembelajaran yang mampu memfasilitasi peserta didik untuk menguasai kemampuan kognitif (Puspithasari, 2019).

Sharon dan James dalam Willyam (2019) mengatakan upaya peningkatan kualitas pembelajaran diperlukan penggunaan tek- 
nologi dan media pembelajaran yang sesuai (Ahmad, 2004). Teknologi dan media dalam pembelajaran dapat membentuk atmosfer pembelajaran yang kondusif, dimana peserta didik dapat berpartisipasi aktif. Media pembelajaran sebagai penghubung antara guru dengan peserta didik. Dengan media peserta didik tidak lagi selalu dibatasi ruang kelas. Peserta didik dapat belajar diberbagai tempat melalui internet maupun ponsel mereka. Selain bermanfaat untuk membuat materi pembelajaran tersampaikan dengan baik, media pembelajaran juga dapat membuat peserta didik menjadi lebih tertarik serta merespon lebih positif, sehingga diharapkan dapat meningkatkan motivasi peserta didik dalam proses pembelajaran (Hairy et al., 2015). Pemilihan media pembelajaran yang tepat oleh guru tidak hanya mencerminkan motivasi pada pembelajaran yang positif, tetapi peserta didik juga dapat merasa senang, menjaga disiplin, dapat meningkatkan pemahaman pengetahuan, dan hasil belajar (Edwin et al, 2018).

Salah satu media yang dapat digunakan yaitu aplikasi Powtoon, dimana cara membuatnya seperti powerpoint namun hasilnya lebih baik yang dapat dibuat dalam bentuk flash, sehingga lebih hidup dan menyenangkan. Powtoon adalah sebuah aplikasi web gratis yang memungkinkan pengguna membuat video dengan mudah. Aplikasi powton dilengkapi berbagai fitur pilihan karakter animasi seperti animasi tangan, kartun, efek transisi yang lebih hidup dan pengaturan timeline yang lebih mudah. Selain itu powton menyediakan fasilitas objek, latar belakang dan musik dalam memudahkan pembuatan sebiah video multimedia pembelajaran yang mampu membuat peserta didik tidak bosan (Alexander, 2017).

\section{Metode Penelitian}

Penelitian dilakukan di Laboratorium Pengembangan Media Pembelajaran Pendidikan Fisika FKIP Universitas Riau pada tahun 2020. Model pengembangan media yang digunakan adalah ADDIE (analysis, design, development, implementation, evaluation). Penelitian dilakukan hanya sampai pada tahap development (Sugiyono, 2016).

Tahap analisis merupakan tahap menganalisis perlunya pengembangan media pembelajaran baru yang sesuai dan menganalisis kelayakan serta syarat-syarat pengembangan. Tahap kedua dari model ADDIE adalah tahap design atau perancangan. Pada tahap ini mulai dirancang media pembelajaran yang sesuai dengan hasil analisis yang dilakukan sebelumnya. Selanjutnya, tahap perancangan dilakukan dengan menentu-kan unsur-unsur yang diperlukan dalam media seperti penyusunan peta kebutuhan media dan kerangka media pembelajaran. Referensi yang relevan juga digunakan sebagai dasar dalam mengembangkan media pembelajaran. Pada tahap ini, disusun apa saja yang perlu ditampilkan pada media yang dikembangkan. Media disusun dengan memperhatikan aspek penilaian media yaitu aspek perancangan, aspek pedagogik, aspek kelayakan isi, dan aspek teknis penggunaan media. Tahap pengembangan merupakan tahap realisasi produk. Pada tahap ini pengembangan media dilakukan sesuai dengan rancangan. Setelah itu, media tersebut divalidasi oleh ahli dan guru (Chaeruman, 2008).

Instrumen yang digunakan oleh ahli dalam memberikan penilaian adalah lembar validasi ahli yang diadaptasi dari (Nasir, 2014). Instrumen ini terdiri dari 4 aspek penilaian beserta item-item penilaiannya. Profil instrumen ditunjukkan oleh Tabel 1.

Tabel 1. Profil instrumen validasi video pembelajaran berbasis Powtoon

\begin{tabular}{clc}
\hline No & \multicolumn{1}{c}{ Aspek Penilaian } & $\begin{array}{c}\text { Jumlah } \\
\text { Item }\end{array}$ \\
\hline 1 & Perancangan & 10 \\
2 & Pedagogik & 10 \\
3 & Isi & 5 \\
4 & Teknis & 7 \\
\hline & \multicolumn{2}{c}{ Total Item } \\
\hline
\end{tabular}

Data validasi pakar dikumpulkan dengan memberikan draft media pembelajaran beserta lembar penilaian kepada tiga orang ahli. Selanjutnya ahli diminta memberikan penilaian yang terdiri dari pendapat serta saran perbaikan, sekaligus skor untuk setiap item menggunakan skala dengan kategori SS (sangat setuju), S (setuju), C (cukup), TS (tidak setuju), dan STS (sangat tidak setuju) yang jika dikonversikan ke dalam angka 
menjadi 5 apabila item yang dimaksud dinilai SS (sangat setuju), 4 apabila item yang dimaksud dinilai $\mathrm{S}$ (setuju), 3 apabila item yang dimaksud dinilai $\mathrm{C}$ (cukup), 2 apabila item yang dimaksud TS (tidak setuju) dan 1 apabila item yang dimaksud dinilai STS (sangat tidak setuju). Data penilaian ahli media pembelajaran selanjutnya ditabulasi. Dari tabulasi tersebut diidentifikasi item-item penilaian yang mendapatkan skor rata-rata $\geq$ 3.4 oleh ahli. Item-item ini selanjutnya harus direvisi sesuai dengan saran perbaikan ahli dan dinilai kembali oleh ahli. Proses ini berlangsung sampai semua ahli menyatakan bahwa semua item sudah memenuhi skor $3.4 \leq$ rata-rata <4.2. Selanjutnya dihitung skor ratarata setiap item penilaian.

Media pembelajaran fisika gerak lurus dalam penelitian ini dapat dinyatakan valid, sehingga layak digunakan apabila seluruh indikator pada instrument validitas memiliki skor rata-rata $\geq 3.4$ yang berada pada kategori tinggi atau sangat tinggi. Maka kriteria validitas media pembelajaran dapat dinyatakan menurut Tabel 2.

Tabel 2. Kriteria Validitas Media Pembelajaran

\begin{tabular}{lc}
\hline $\begin{array}{c}\text { Interval Rata-Rata } \\
\text { Skor }(\mathbf{r})\end{array}$ & Nilai Validitas \\
\hline $4.2 \leq \mathrm{r} \leq 5$ & Valid \\
$3.4 \leq \mathrm{r}<4.2$ & Valid \\
$2.6 \leq \mathrm{r}<3.4$ & Tidak Valid \\
$1.8 \leq \mathrm{r}<2.6$ & Tidak Valid \\
$1 \leq \mathrm{r}<1.8$ & Tidak Valid \\
\hline
\end{tabular}

\section{Hasil dan Pembahasan}

\section{Tahap Perancangan (Design)}

Tahap pertama pada penelitian ini adalah tahap Analisis. Melalui tahap ini dilakukan analisis kebutuhan, analisis kurikulum, dan analisis karakteristik peserta didik. Tahap analisis kebutuhan bertujuan mengidentifikasi sejauh mana pembelajaran fisika di kelas $\mathrm{X}$ SMAN 1 Bandar Petalangan dilaksanakan. Berdasarkan hasil survey dan wawancara yang dilakukan kepada peserta didik dan tenaga pendidik di SMAN 1 Bandar Petalangan mengenai proses pembelajaran fisika.
1) Pertanyaan 1: Apa yang membuat kamu sulit dalam memahami pelajaran fisika?

Peserta didik: Kami sulit memahami pelajaran fisika disebabkan oleh metode pembelajaran yang digunakan oleh guru, pembelajaran yang dilakukan hanya dengan metode ceramah, membahas rumus dan langsung menerapkannya pada persamaan soal. Sehingga membuat kami cepat mengantuk dan bosan.

2) Pertanyaan 2: Apakah pernah disaat proses pembelajaran menggunakan video pembelajaran?

Peserta didik: Tidak pernah, pada proses pembelajaran tidak pernah menggunakan media pembelajaran termasuk dalam bentuk video pembelajaran. Selama ini yang digunakan hanya lembar kerja peserta didik.

3) Pertanyaan 3: Kalian tentu sudah belajar materi gerak lurus kan? Apa menurut kalian pelajaran ini susah atau mudah? Kenapa demikian?

Peserta didik: Susah, pelajarannya susah dimengerti, banyak sekali rumus yang harus dipahami, dan juga sulit untuk memahami dengan baik penjelasan yang guru berikan.

4) Pertanyaan 4: Apakah selama kegiatan belajar mengajar guru pernah menggunakan media pembelajaran sebagai alat bantu mengajar?

Guru: Tidak pernah menggunakan media pembelajaran, yang diguanakan hanya lembar kerja peserta didik.

5) Pertanyaan 5: Apa yang menyebabkan guru tidak menggunakan media pem-belajaran selama proses kegiatan belajar mengajar?

Guru: Karena sebagian guru masih tabu terhadap media pembelajaran dan masih kurang paham mengenai IT.

Hasil wawancara yang dilakukan, peserta didik sulit untuk memahami pelajaran fisika karena metode pembelajaran yang dilakukan oleh guru, pembelajaran sering kali dilakukan dengan menggunakan metode ceramah, sehingga kurang menarik perhatian peserta didik yang membuat peserta didik cepat mengantuk dan bosan. Selain itu, materi gerak lurus dalam fisika dianggap sulit untuk dipahami. Banyak rumus yang harus digunakan dan peserta didik masih menghafal rumus yang diberikan guru tanpa mencari tau 
rumus itu berasal dan tanpa memahami konsepnya.

Melalui proses kegiatan belajar mengajar guru sangat jarang menggunakan media pembelajaran dikarenakan kurang pemahaman guru terhadap IT. Oleh karena itu, peneliti membuat media pembelajaran berbentuk video menggunakan aplikasi Powtoon, dimana media ini mudah dalam pembuatan dan juga mudah dalam penggunaan. Sehingga dapat memudahkan guru dalam membuat suatu media pembelajaran. Media pem-belajaran berbentuk video ini dapat membantu meningkatkan motivasi dan prestasi belajar peserta didik.

Berdasarkan analisis kurikulum, telah dianalisis dokumen berupa silabus mata pelajaran fisika SMA kelas X dan peta konsep pada materi pembelajaran gerak lurus. Dari hasil analisis kurikulum, dapat ditentukan unsur apa saja yang diperlukan dalam mengembangkan media pembelajaran.

Tahap Perancangan (Design)

Media pembelajaran yang dimaksud berupa video pembelajaran fisika berbasis Powtoon pada materi gerak lurus. Dimana pada history board terdapat 9 video. Video pertemuan 1 yaitu materi gerak lurus beraturan dan terdapat 2 video yaitu video latihan dan evaluasi. Video pertemuan 2 yaitu materi gerak lurus berubah beraturan dan terdapat 2 video yaitu video latihan dan evaluasi. Video pertemuan 3 yaitu materi gerak vertikal dan terdapat 2 video yaitu video latihan dan evaluasi. Video kompetensi yang didalamnya menjelaskan kompetensi inti, kompetensi dasar, dan indikator pembelajaran. Video profil peneliti, dan video FAQ (frekuensi ask question).

\section{Tahap Pengembangan (Development)}

History board menjadi acuan dalam tahap pengembangan media pembelajaran. Media pembelajaran yang dibuat adalah video pembelajaran menggunakan aplikasi Powtoon. Membuka aplikasi Powtoon menggunakan opera browser kemudian mengakses link www.powtoon.com. Setelah itu dilakukan sign-up atau pendaftaran dengan menggunakan akun google. Selanjutnya akan muncul variasi template yang dapat dipilih dan akan muncul area kerja aplikasi Powtoon serta kita dapat menggunakan fitur-fitur, animasi yang telah disediakan oleh Powtoon. Gambar
1, 2 dan 3 berikut merupakan tampilan awal dari video pembelajaran yang dibuat dengan Powtoon.

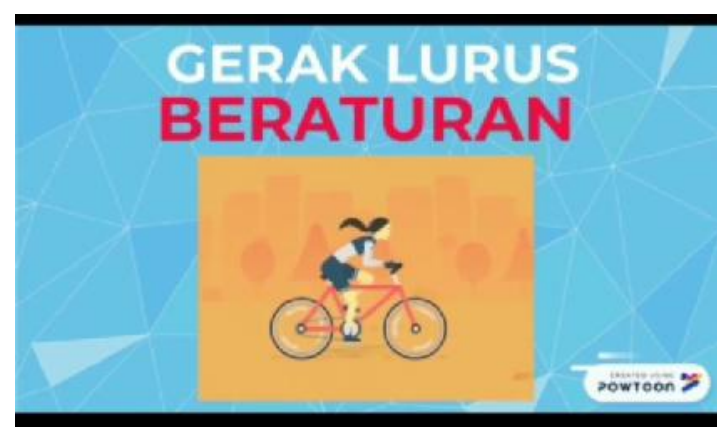

Gambar 1. Tampilan awal video pembelajaran materi GLB.

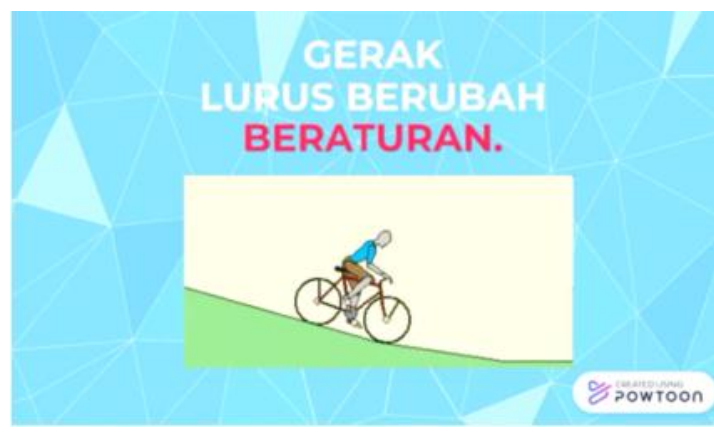

Gambar 2. Tampilan awal video pembelajaran materi GLBB.

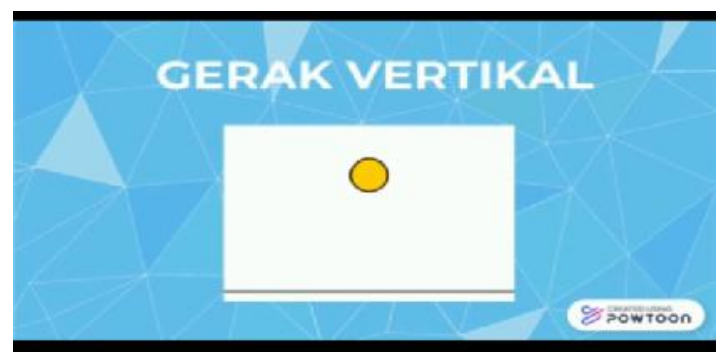

Gambar 3. Tampilan awal video pembelajaran materi gerak vertikal.

Gambar 1, 2, dan 3 menampilkan video pembelajaran yang berisikan judul materi serta gambar animasi yang sesuai dengan judul. Gambar 1 video tentang gerak lurus beraturan, gambar 2 video tentang gerak lurus berubah beraturan dan Gambar 3 video tentang gerak vertikan. Setelah tampilan layar utama video pem-belajaran, selanjutnya ditampilkan indikator pembelajaran. Kita dapat melalkukan pause 
video jika ingin membaca indikator ataupun materi yang akan dibahas selanjutnya.

Hasil validasi media pembelajaran dapat dilihat pada Tabel 3, 4, dan 5. Tabel 3 untuk video gerak lurus beraturan menunjukkan hasil semua aspek valid dengan rata-rata skor 4,31 (Valid). Tabel 4 untuk video gerak lurus berubah beraturan diperoleh semua aspek valid dengan skor rata-rata 4,36 (valid). Demikian pula Tabel 5 untuk video gerak vertikal, diperoleh kategori valid pada semua aspek, sehingga skor rata-ratanya 4,37 (Valid). Dengan demikian ketiga video dinyatakan valid sebagai media pembelajaran di kelas $\mathrm{X}$ SMA pada materi gerak lurus.

Tabel 3. Penilaian validitas video pertemuan 1 (GLB)

\begin{tabular}{clcc}
\hline No & \multicolumn{1}{c}{ Aspek } & Skor & Keterangan \\
\hline 1 & $\begin{array}{l}\text { Aspek } \\
\text { perancangan }\end{array}$ & 4.27 & Valid \\
2 & $\begin{array}{l}\text { Aspek } \\
\text { pedagogik }\end{array}$ & 4.28 & Valid \\
3 & Aspek isi & 4.42 & Valid \\
4 & Aspek teknis & 4.3 & Valid \\
\hline & Nilai Validitas & 4.31 & Valid \\
\hline
\end{tabular}

Tabel 4. Penilaian validitas video pertemuan 2 (GLBB)

\begin{tabular}{clcc}
\hline No & \multicolumn{1}{c}{ Aspek } & Skor & Keterangan \\
\hline 1 & Aspek & 4.33 & Valid \\
& perancangan & & \\
2 & Aspek & 4.31 & Valid \\
& pedagogie & & \\
3 & Aspek isi & 4.42 & Valid \\
4 & Aspek teknis & 4.38 & Valid \\
\hline \multicolumn{2}{l}{ Nilai Validitas } & 4.36 & Valid \\
\hline
\end{tabular}

Tabel 5. Penilaian validitas video pertemuan 3 (gerak vertikal)

\begin{tabular}{clcc}
\hline No & \multicolumn{1}{c}{ Aspek } & Skor & Keterangan \\
\hline 1 & Aspek & 4.32 & Valid \\
& perancangan & & \\
2 & Aspek & 4.35 & Valid \\
& pedagogie & & \\
3 & Aspek isi & 4.42 & Valid \\
4 & Aspek teknis & 4.4 & Valid \\
\hline & Nilai Validitas & 4.37 & Valid \\
\hline
\end{tabular}

Jika skor ketiga video tersebut diambil nilai validasi rata-ratanya, maka mendapat skor 4,34. Jadi video pembelajaran berbasis Powtoon pada materi gerak lurus untuk SMA kelas $\mathrm{X}$ dinyatakan telah valid pada kategori sangat tinggi.

Tahap analisis kebutuhan bertujuan mengetahui sejauh mana pembelajaran fisika di kelas X SMAN 1 Bandar Petalangan dilaksanakan. Berdasarkan hasil survey yang dilakukan kepada peserta didik dan tenaga pendidik di SMAN 1 Bandar Petalangan mengenai proses pembelajaran fisika, menurut beberapa peserta didik selama ini mereka kurang memahami dan kurang tertarik terhadap mata pelajaran fisika disebabkan oleh metode pembelajaran yang digunakan oleh tenaga pendidik. Peserta didik juga mengatakan bahwa selama pembelajaran fisika, mereka sangat jarang melakukan kegiatan eksperimen langsung di labor, pembelajaran yang dilakukan cederung monoton dengan ceramah, membahas rumus dan langsung menerapkannya pada persamaan soal.

Peserta didik dalam pembelajaran dituntut langsung untuk memahami rumus fisika, tanpa adanya penjelasan terlebih dahulu tentang teori maupun konsep yang berkaitan dengan materi pembelajaran yang akan dipelajari. Banyak peserta didik yang tidak memberikan hasil yang baik dalam pembelajarannya (Ma'rifa \& Fihrin, 2013). Peserta didik tidak mengetahui cara-cara belajar yang efisien dan efektif, karena hanya mencoba menghafal pelajaran. Padahal fisika bukan materi untuk dihafal, melainkan memerlukan penalaran dan pemahaman konsep. Akibatnya jika diberi tes, peserta didik mengalami kesulitan.

Peserta didik juga mengungkapkan bahwa selama mereka belajar fisika sangat jarang sekali dalam pembelajaran menggunakan media pembelajaran dan kebanyakan guru dalam proses penyampaian konsep kepada peserta didik cenderung hanya menyampaikan konsep dalam bentuk singkat, sehingga hanya sedikit pelajaran yang dipahami dan diingat oleh peserta didik. Peserta didik hanya dapat mengingat materi pelajaran sebanyak 5\% hingga $10 \%$ dari yang mereka baca didalam buku bacaan, tetapi mereka dapat mengingat hingga $80 \%$ dari yang mereka alami ataupun dikerjakan langsung (Farida \& Andista, 2016).

Selanjutnya, survey terhadap tenaga pendidik fisika di SMAN 1 Bandar Petalangan, mengungkapkan bahwa didalam proses pem- 
belajaran fisika sangat jarang menggunakan media pembelajaran elektronik, jarang melakukan praktikum di labor, dikarenakan alat dan bahan labor yang tidak memadai atau tidak layak pakai, para pendidik juga mengungkapkan bahwa mereka tabu pada media pembelajaran berbasis elektronik. Selama proses pembelajaran fisika, media pembelajaran yang di gunakan hanya berupa LKPD (Lembar Kerja Pesera Didik).

Proses belajar mengajar menggunakan media pembelajaran berupa video pembelajaran, mempermudah para pengajar untuk mendapatkan materi dan lebih mengembangkan lagi dalam metode pengajaran. Selain itu pembelajaran menggunakan video pembelajaran lebih meringankan tenaga pendidik, karena tenaga pendidik berperan sebagai fasilitator dan tidak lagi berbicara panjang lebar dengan model ceramah. Karena jika hanya dengan metode ceramah, peserta didik menganggap hal tersebut tidak menarik. Dwi (2009) mengatakan metode ceramah menyebabkan peserta didik tidak berminat dan sulit dalam belajar fisika. Metode pembelajaran fisika dengan ceramah seharusnya dipadukan dengan metode yang lebih meningkatkan keaktifan peserta didik dalam proses belajar mengajar di kelas. Oleh karena itu, peserta didik memperoleh pengalaman secara langsung.

Kelebihan menggunakan media pembelajaran seperti video yang berbasis Powtoon yaitu membuat peserta didik lebih tertarik belajar mengenai materi pembelajaran dan membangkitkan motivasi peserta didik, karena Powtoon merupakan aplikasi yang mengikuti tren zaman sekarang, hasil video yang dibuat melalui Powtoon dapat dipublish lewat facebook dan youtube, peserta didik ataupun tenaga pendidik bisa langsung men-download video pembelajaran. Video pembelajaran menggunakan Powtoon mudah dalam penggunannya, dapat dilakukan dimana saja dan kapan saja, baik didalam kelas ataupun diluar kelas dan tidak lagi mengandalkan tenaga pendidik saja sebagai narasumber tunggal.

Hasil kajian yang diperoleh ini didukung oleh penelitian Ima (2018) yang mengembangkan media pembelajaran fisika berbasis Powtoon pada materi dinamika, mendapat skor penilaian ahli media dan ahli materi $83 \%$ yang termasuk kedalam kategori sangat baik. Selain itu, sejalan juga dengan penelitian Khusnul (2018) yang mengembangkan video animasi berbasis Powtoon untuk model pembelajaran flipped classroom pada materi termodinamika. Yang mendapatkan skor $83.50 \%$ yang ber-kategori layak sebagai media pembelajaran fisika. Hasil dari kedua kajian tersebut menggunakan jenis media yang sama yaitu aplikasi Powtoon.

Pengembangan media pembelajaran ini dilakukan demi memberikan solusi alternatif dalam pemecahan masalah tentang bagaimana mengajarkan pembelajaran fisika untuk materi gerak lurus yang memiliki teori dan penerapan matematis yang masih abstrak dalam pemahaman peserta didik. Dengan menggunakan video pembelajaran berbasis Powtoon sebagai media pembelajaran dapat memvisualisasikan seluruh materi gerak lurus. Pengembangan media pembelajaran menggunakan aplikasi Powtoon merupakan aplikasi yang sangat baik untuk dijadikan media pembelajaran, karena Powtoon memiliki fiturfitur yang lebih lengkap dibanding aplikasiaplikasi online lainnya.

Kendala yang dihadapi selama pembuatan media pembelajaran fisika berbasis Powtoon pada materi gerak lurus ialah jaringan atau internet, karena aplikasi Powtoon merupakan aplikasi online yang bisa digunakan jika terhubung dengan internet. Pemilihan gambar, tulisan, dan animasi yang digunakan untuk media juga menjadi salah satu kendala yang sampai akhirnya media berhasil dibuat. Aplikasi Powtoon juga dibatasi waktu penggunaannya dimana dapat digunakan secara gratis dalam jangka waktu 3 hari. Jika melewakti waktunya, maka pada hari berikut-nya gambar, teks dan template yang digunakan akan terbatas. Kelebihan media pembelajaran berbasis Powtoon dapat meningkatkan kemampuan kognitif peserta didik karena media ini menampilkan pembelajaran dalam bentuk visual dan audiovisual.

\section{Kesimpulan}

Media pembelajaran fisika berbasis Powtoon telah berhasil dirancang untuk tiga pertemuan yang mencangkup materi pembelajaran gerak lurus untuk SMA kelas X. Media pembelajaran fisika berbasis Powtoon 
dapat meningkatkan kemampuan kognitif peserta didik, karena dapat menampilkan pembelajaran dalam bentuk visual dan audiovisual, yang membuat peserta didik tertarik dan termotivasi untuk mengikuti proses pembelajaran. Media pembelajaran berbasis Powtoon juga dapat di akses dimana saja dan kapan saja selama video masih tersimpan di galeri peserta didik. Media pembelajaran ini telah divalidasi oleh ahli dan ahli memberikan nilai setiap aspek dengan kategori valid, sehingga dinyatakan layak digunakan dalam pembelajaran pada materi gerak lurus di kelas X SMA.

Hasil pengembangan media ini diharapkan dapat dilanjutkan lagi pada tahap implementasi. Media ini dapat dijadikan acuan untuk lebih berinovasi membuat media pembelajaran pada aplikasi Powtoon. Banyak materi pembelajaran fisika lain yang bisa dibantu penjelasannya menggunakan aplikasi Powtoon, sehingga pembelajaran menjadi lebih baik dan lebih efisien.

\section{Daftar Pustaka}

Ahmad, R. (2004). Pengelolaan Pengajaran. Jakarta. PT. Rineka Cipta.

Alexander, N. (2017). Teaching English Through the Use of Cloud-Based Animation Software Powtoon. TESOL Journal, 2(3), 2.

Chaeruman. (2008). Mengembangkan Sistem Pembelajaran dengan Model ADDIE. Jakarta: PT. Remaja Rosdakarya.

Dwi, A. (2009). Skripsi: Peningkatan Pemahaman Siswa Tentang Gerak Lurus Menggunakan Metode Simulasi Komputer Di SMA 1 Karangnongko Klaten. Universitas Sanata Dharma: Yogyakarta.

Edwin, N., Emil, E. F., \& Sulkipani. (2018). Pengembangan Media Pembelajaran Berbasis Powtoon Pada Perkuliahan Pendidikan Kewarganegaraan. Jurnal Civics: Media Kajian Kewarganegaraan, 15(1).

Farida, H., \& Andista, C. (2016). Pengembangan Odd "Osilator Digital Detector" Sebagai Alat Peraga Praktikum Gerak Harmonik Sederhana. Jurnal Inovasi dan Pembelajaran Fisika. ISSN:
2355-7109. FKIP Universitas Sriwijaya. Sumatra Selatan.

Hairy, M. C., I Made, A., \& Erfan Handoko. (2015). Pengembangan Alat Peraga Resonansi dan Efek Doppler Berbasis Soundcard Pc/Laptop untuk Meningkatkan Motivasi Belajar Fisika Siswa SMA, $4,2$.

Ika, R. J., Muchsini, B., \& Wahyu, A. (2016). Model Pembelajaran Artikulasi dengan Media Animasi Powtoon untuk Meningkatkan Prestasi Belajar Mata Pelajaran Akuntansi Keuangan. Jurnal Pendidikan Akuntansi, 2(2), 2.

Ima A. M. (2018). Pengembangan Media Pembelajaran Fisika Berbasis Powtoon pada Materi Dinamika Untuk SMA Kelas X. Skripsi.

Khairul, B. (2004). Mengkaji Kembali Pengajaran Fisika di Sekolah Menengah (SMP dan SMA) di Indonesia. Inovasi Online, 2(XVI). http://io.ppi-jepang.org/ article.php?id $=45$.

Khusnul, B. (2018). Pengembangan Video Animasi Berbasis Powtoon untuk Model Pembelajaran Flipped Classroom pada Materi Termodinamika. ISBN : 978-6025614-35-4.

Ma rifa, H. K., \& Fihrin, H. (2013). Analisis Pemahaman Konsep Gerak Lurus pada Siswa SMA Negeri di Kota Palu. Jurnal Pendidikan Fisika Tadulako (JPFT), 4(3), 1-3.

Nasir. M. (2014). Development and Evaluation of the Effectiveness of Computer-Assisted Physics Instruction. International Educational Studies 7 (13)14-23.

Puspithasari. L. (2019). Pengaruh Model Pembelajaran POE (Predict-Observe Explain) dengan Teknik Probing Prompting terhadap Penguasaan Konsep Gerak Lurus. Jurusan Fisika. Fakultas. MIPA UM.

Sugiyono. (2016). Metode Penelitian dan Pengembangan. Bandung: Alfabeta.

Tobing, D. L. (1996). Fisika Dasar 1. Jakarta (ID): Erlangga.

Willyam, S. A., Rahmad, M., Muhammad Syafi'I, M., \& Nurliana. (2018). Physics Learning Blog Development Based On Flipped Classroom Approach For Grade $X$ Mipa Senior High School. Jurnal Geliga Sains 6(2), 75-84. 